\title{
Economic Policymaking in the Guided Democracy (1962-1965)
}

\begin{abstract}
This chapter explores the economic policy making during the Guided Democracy, especially during the late-Guided Democracy period as it neared its end by 1965 , and the increasing polarization between expert economists and the communist party. It looks into communist economic ideas that goes in line with Sukarno's participatory ideas in the economy and how expert economists tried to incorporate socialist models in the economy through researching the economic institutions of East European countries and the Soviet Union. Efforts to integrate liberal economic theories with socialist institutions were discussed in the context of continuing economic deterioration of the first half of the 196os. A series of economic reform programs designed by Indonesian economists, often working with expert from the US. While initially obtaining support from Sukarno, these economic reforms flounder as a result of communist criticism and Sukarno's unwavering stance to support a more populist position when under pressure. The period saw the return home of many of New Order's main economists after graduating from US universities and their positioning into important post in the economic planning and control of the country. It was a period which cemented the rise of American-educated economists as major holder of Indonesian policy making and the subsequent fall of the Indonesian communist model of the economy.
\end{abstract}

\section{Keywords}

Indonesian socialism - Deklarasi Ekonomi - communist production policy - rise of Indonesian technocracy

Economic policymaking during the latter part of the Guided Democracy showed increasing polarization between the populist nationalist sentiments that Sukarno espoused and the ideas of the economic experts who began to be courted by the executive to help design strategies to cope with the deteriorating 
economic conditions. Both nationalists and communists supported taking a stronger stance against what they perceived to be the threat of economic imperialism from the Bretton Woods organizations. The communists developed their own economic ideas in the form of the production approach and pushed for the greater inclusion and participation of labour unions, farmer unions, and other economic actors within both the state-owned sector and the reorganized private sector. They supported the nationalization of foreign-owned companies, and the trade unions initiated the nationalization of British companies in 1963-1964.

This chapter looks at the work of the new class of policymakers that was created during the 1950s and early 196os through the provision of international and government aid for higher education. This new class of economists was pragmatic and open to Sukarno's state-led socialist ideas. Although Sukarno had continued reservations about so-called experts, the economists - for instance, Foreign Minister Soebandrio and Minister of Industry Chairul Saleh - gained allies within Sukarno's inner sanctum. While the communists supported the de-concentration of the control of companies in order to allow the greater participation of labour unions and other groups, Western-educated economists also supported de-concentration, but with the aim of gradually introducing the market mechanism into the economy; however, they saw this process as occurring within the confines of state control over market forces. The efforts made to rehabilitate the economy after 1963 provide a glimpse of the increasing tension between these two economic models.

\section{Guided Democracy and Economists}

The earliest economists to play a significant role in the Guided Democracy state had finished their bachelor's degrees in the mid 1950s, as the first and most important Faculty of Economics had opened its doors at UI in 1951. The mid 195os were propitious times for newly graduated economists because of the availability of scholarships at the various old and newly minted foreign academic institutions. The first-generation economists, including Mohammad Sadli, Sarbini Sumawinata, and Suhadi Mangkusuwondo, had started to find their way home to Indonesia by the late 1950s, but it was not until 1962 that a significant and increasing number of economists and other social scientists started to return to Indonesia from the United States.

Many of these new economists had good revolutionary credentials. During the independence struggle, Suhadi Mangkusuwondo had fought in the same 
student army company as Widjojo Nitisastro. ${ }^{1}$ As the older generation of economists faded away, the new generation was able to take up official positions in the state. None of them advocated a direct application of the market-based approach to economic policymaking and, especially during the Guided Democracy, they were quite supportive of the idea of a state-led economy that gave a prominent role to state-owned companies. In the words of Mangkusuwondo:

During the period of Guided Democracy and Guided Economy in the early 196os, our attention was focused on the question of how to operate a planned economy based on socialist principles, in which state-owned enterprises (SOEs) were to occupy the 'commanding heights of the economy' and to be its driving force. As economists, we were concerned that the market mechanism be allowed to operate in a planned economy based on socialist principles. Hence, Oscar Lange's views on a socialist market economy became the model for our own views on how to run Indonesia's Guided Economy.

Keynesianism had to be worded differently so that it conformed to the Revolusi ideology. Sukarno had not permitted the teachings of Keynes in Indonesian universities since the early 196 os. $^{2}$

R. Soerjadi, an economist with communist leanings who had worked as the Central Bank's director for economic planning and statistics, presented a paper at a meeting of the Indonesian Scholars Association (Himpunan Sardjana Indonesia, HSI), ${ }^{3}$ a communist-affiliated organization, in August 1963. He focused on the perceived similarity between the extremes of communist and capitalist societies and where socialism existed within the continuum. It was assumed by neo-liberal economists such as Von Mises, Ropke, Hayek, and Simons that government intervention was admissible in the economy to control the market. In an analysis of the socialist economist Abraham P. Lerner's The Economics of Control, Soerjadi disputed Lerner's conclusion on the concept of pragmatic collectivism: 'Pragmatic as contracted with domestic collectivism is very close to the point of view of the liberal capitalist, who is in favour of state activity wherever the liberal capitalist ideal of perfect competition cannot be made to work. ${ }^{4}$ He then proceeded to quote Dutch economist and politician

1 Mangkusuwondo, 'Recollections of My Career', 34.

2 Anwar, Sukarno, Tentara, PKI, 15.

3 The HSI was a communist-affiliated organization of academics and economists.

4 Quoted by R. Soerjadi,, 'Sistim Ekonomi Terpimpin dibidang Moneter', speech given at the HSI Economic Seminar, 20 July 1963, 6. ANRI, Roeslan Abdulgani, inv. no. 1082. 
Jelle Zijlstra in his book Economische orde en economische politiek: 'If the thoughts of Simons, Hayek, and Ropke, who call for government intervention in the economy, are acceded to, then the thoughts of Hayek and Ropke will reach the conclusion that the Government must intervene in the matters of "work opportunity, monopoly, and the allocation of national income, which are the three subjects that according to Lerner require attention within a "controlled economy".5

Soerjadi's paper was meant to show that an economic system was not automatically tied to an ideology. The overlapping thoughts expressed by socialists and neo-liberals showed the fragility of this fallacy: 'As a result, it can be said that a society can have more than one characteristic. This means that, for instance, liberal societies cannot be identified by just one characteristic, for instance "an economically free society", nor can a communist society be identified by just one characteristic, for instance "a Guided Economy society".' Instead, he says, 'one can say that a Guided Economic society is not identical to communism. In other words, the guided economic system can be combined with other characteristics that do not exist in Russia. This is the case in Indonesia, where the implemented economic system is a guided economic system. But its ideology is that of the Pantjasila in a society that is familiar with musjawarah, gotong rojong, ownership rights with social functions, et cetera.'

\section{$2 \quad$ The Study of Socialist Economies}

From 1960, economists at various universities started studying the state-led economic models in Eastern Europe and China and tried to develop strategies for the Guided Democracy state. The LPEM and other research institutions

5 Quoted by Soerjadi, 'Sistim Ekonomi Terpimpin dibidang Moneter', ANRI, Roeslan Abdulgani, inv. no. 1082 .

6 Quoted by Soerjadi, 'Sistim Ekonomi Terpimpin dibidang Moneter', ANRI, Roeslan Abdulgani, inv. no. 1082. 'Dengan demikian dapat dikatakan, bahwa suatu masjarakat itu mempunjai lebih dari satu tjiri sadja. Ini berarti, bahwa misalnja masjarakat Liberal itu, tidak dapat kita beri identifikasi, dengan menjebut satu tjiri sadja dari padanja, umpamanja: "masjarakat ekonomi bebas", dan masjarakat Komunis itu tidak dapat kita beri identifikasi dengan menjebut satu tjiri sadja daripadanja, misalnja "masjarakat ekonomi terpimpin". And: '...sistim ekonomi terpimpin itu tidak identik dengan komunisme. Dengan pertakaan lain, sistim ekonomi terpimpin itu dapat dikombinasikan dengan lapangan2 lain jang sifatnja berlainan dengan jang terdapat di Rusia. Demikianlah, di Indonesia telah ditetapkan, bahwa sistim ekonomi jang hendak didjalankan, ialah sistim ekonomi terpimpin, dasar negara ialah Pantjasila, masjarakat jang mengenal musjawarah dan gotong-rojong, hak milik jang mempunjai fungsi sosial, dsb.' 
conducted surveys in various countries abroad and made research visits to farflung parts of the archipelago to obtain the knowledge necessary to develop an Indonesianized version of a mixed economy. The edited volume produced, titled Tata Perekonomian Sosialis Indonesia (Indonesia's socialist economic system), was perhaps one of the most important outcomes; in it, economists from the UI compared and analysed the economic system of Indonesia with those of its Eastern European equivalents. ${ }^{7}$ Other significant works included one by Widjojo Nitisastro, who conducted a series of interviews with Polish planning elites and found that their consumption pattern projections were based on West German consumption patterns. ${ }^{8}$ Panglaykim's book broadly discussed the various managerial approaches of several Eastern European countries and the People's Republic of China, ${ }^{9}$ Wahju Sukotjo wrote about Yugoslavia's worker's management council and socialist democracy in an article for the magazine Ekonomi, while another article for the same magazine by Mohammad Sadli and Subroto concerned Yugoslavia's socialist economic system. R. Sardju Ismunandar and Soehardiman visited Yugoslavia, Czechoslovakia, and Poland and wrote about the economic structure and state enterprises of the three countries in the magazine Perusahaan Negara in May $1961 .^{10}$

Panglaykim's studies showed that even socialist states entertained ideas of implementing capitalist concepts such as private enterprise. His study on Chinese and East German state capitalism explained this as being part of a transitional phase that compromised its socialist ideals through the introduction of public and private ownership for government companies. His discussion of the Soviet model of national planning occurred after Khrushchev's proclamation of the USSR's sixth Five-Year Plan (1956-196o), which focused on efficiency and giving greater managerial independence to regional bodies and companies. ${ }^{11}$ Widjojo Nitisastro suggested actively importing Western ideas through the prism of socialism by looking at what other socialist countries had imported, such as input-output analyses and various programming techniques. ${ }^{12}$ The

Suhadi Mangkusuwondo (ed.), Tata Perekonomian Sosialis Indonesia (Jakarta: LPEM, 1962).

8 Mohammad Sadli, 'Masalah Penentuan Produksi dan Masalah Bentuk Perusahaan dalam Sistim Sosialisme Indonesia', in Suhadi Mangkusuwondo (ed.), Tata Perekonomian Sosialis Indonesia (Jakarta: LPEM, 1962), 107-8.

Panglaykim, 'Beberapa Aspek Struktur Management/Organisasi pada Beberapa Negara Sosialis', in Suhadi Mangkusuwondo (ed.), Tata Perekonomian Sosialis Indonesia (Jakarta: LPEM, 1962), 126-296.

10 Sardju Ismunandar and Soehardiman, 'Struktur Ekonomi dan Perusahaan Negara di Jugoslavia, Czechoslovakia dan Polandia', Perusahaan Negara, 1/5 (May 1960), 2-6.

11 Panglaykim, 'Beberapa Aspek Struktur Management', 125-82.

12 Widjojo Nitisastro, 'Beberapa Persoalan Harga', in Suhadi Mangkusuwondo (ed.), Tata Perekonomian Sosialis Indonesia (Jakarta: LPEM, 1962), 102. 'Untuk penelahaan persoalan 
Keynesian Harrod-Domar model of development, which focused on savings and foreign investment as being central to the push for economic growth, was also studied. ${ }^{13}$

Papers written by some of the most important technocrats of the New Order illustrate the efforts they made to integrate Western theories and socialist institutions harmoniously. Although Sadli claimed that the prime importance of the market was realized later on, ${ }^{14}$ efforts were made to understand how other socialist countries used the market. For instance, the Polish use of the West German consumption model showed that even within a relatively developed socialist economy, 'markets and price mechanism still work and determine production volume. ${ }^{15}$ Sadli and Soebroto attended a seminar on Marxism and socialist development in Belgrade from 5 to 22 September 1960 and commented on the Yugoslavian socialist system: 'In the 1950s the basic policy of a stateled nationalist economy was changed. The Russian model was left behind because it was considered inefficient and unfit for Yugoslavian characteristics. Market and price-based stimuli were reintroduced.'16

The role of private enterprise in various communist countries was also discussed: in Russia, 'private enterprise is allowed to exist only in branches of production which can be operated as one-man industries. ${ }^{17}$ In contrast, in Poland, private enterprise 'is given the widest latitude in the field of production to augment the available consumer goods, to open new fields of production which have never been developed before, to give employment to more people, and to

pembagian pendapatan, perkembangan berbagai matjam sistim2 ekonomi dsb., arah jang ditempuh kiranja ialah pertumbuhan suatu ilmu ekonomi dalam arti political economy, jang hanja dapat disusun sebagai suatu usaha inter-disciplinary study diantara ilmu2 pengetahuan sosial jang ada.'

13 Kaptin Adisumarto, 'Scope and Limits of the Harrod-Domar Equilibrium Formula with Respects to Various Economic Models and Their Policy Implications', in Laporan Kongres Ilmu Pengetahuan Indonesia Kedua, 1962, Djilid Ix: Seksi E-3 (Ekonomi) (Bogor: Archipel, 1962), 209-32. The focus on domestic savings and foreign investment was central to the 1956-196o Development Plan of the BPN.

14 Sadli, 'Recollections of My Career', 27.

15 Sadli, 'Masalah Penentuan Produksi', 110.

16 Mohammad Sadli and Soebroto, 'Tata Ekonomi Sosialis Jugoslavia', Ekonomi, 84. 'Dalam tahun 1950 dasar kebidjaksanaan negara untuk mengusahakan ekonomi nasional diubah. Model Russia ditinggalkan sebab dipandang tidak effisien dan tidak tjotjok dengan keadaan2 jang terdapat di Jugoslavia setjara chas. Sistim perangsang dikembalikan dengan pengunaan sistim pasar dan harga (bebas).'

17 Subroto, 'The Role of Private Enterprise in the Framework of Indonesian Socialism, in Johnson J. Rossel, Mohammad Sadli and Subroto (eds), Teachings in Business Administration and Economics (Jakarta: LPEM, 1961), 26. 
increase the prosperity of the country'.18 What was perhaps the most common characteristic in the trope used by FEUI economists was the assumption that the communist and the capitalist worlds represented a difference in degree and not in kind.

The focus on studying Eastern European socialism was encouraged by Mohammad Sadli and indicated the need for experts on the subject. Batara Simatupang, an assistant lecturer at the FEUI, was part of the second group of economics students from the UI that was sent, along with Emil Salim, to study in the United States. Studying at Stanford under, among others, Paul Baran, Simatupang examined neo-Marxist ideas that were the precursors to the dependency theory of the 1970s. There was thus a recognition within the FEUI that socialist ideas on economic planning and development should be studied. Simatupang was then sent to Yugoslavia, where he studied the work of the country's planning board. After that, he went to Poland to pursue his PhD. ${ }^{19}$

\section{Economic Deterioration and Rehabilitation}

By 1962, there was a widespread acknowledgement that the economic situation had become dire. A comparison of the situations in 1961 and 1965 gives a vivid picture of the deteriorating conditions. Indonesia's GDP (constant price 1960) increased from Rp 390.5 billion in 1960 to $\mathrm{Rp} 429.7$ billion in 1965, with annual growth of 2.2 per cent and annual population growth of 2.8 per cent. Thus, GDP per capita had an annual negative growth rate of o.6 per cent. Exports had fallen from $\$ 620$ million in 196 o to $\$ 462.7$ million in 1965 , down 30 per cent. With an increase in the population of about 3 o per cent ${ }^{20}$ in the same period, foreign exchange per capita had decreased by a huge 6o per cent. Foreign debt grew from around $\$ 900$ million in 1961 to about $\$ 2,25$ billion by 1966 , an increase of 250 per cent. For the year 1966 the total debt payment, including interest, equalled around $\$ 530$ million, because some longer-term debts had matured. This sum was larger than the entire national-export income. Even more uncontrollable was the problem of the deficit. Money in circulation by

18 Subroto, 'The Role of Private Enterprise', 26.

19 Batara Simatupang, Otobiografi DR. Batara Simatupang (Jakarta: Del, 2012), 63-76. After the fall of the Guided Democracy, Simatupang was not allowed to return to Indonesia and emigrated to West Germany.

20 This was based on Bintoro Tjokroamidjojo's calculations. Population growth rates of $2.8 \%$ would have increased the total population in five years by around $11 \%$. Because of a lack of accurate data, it is uncertain which numbers were more representative of reality. 
July 1966 had an increase of 23,887 per cent. The government deficit grew from Rp 6.9 million in 1960 to Rp 5,24 billion in the same period. During the latter part of the Guided Democracy, inflation was always above 100 per cent annually. This situation severely affected consumers, as food prices between 1961 and 1966 increased forty-fold, and eight-fold in 1965 alone. ${ }^{21}$

A significant contributor to the economic woes was the reduced efficiency of large parts of the state-owned companies that had previously been under foreign management. Between 1957/1958 and 196o, Dutch nationalized companies were arranged under a variety of government supervisory bodies, grouped according to their industrial field: the BUD for commercial enterprises, Bappit for industry and mining, and New State Estates Company (Perusahaan Perkebunan Negara Baru, PPN-Baru) for industrial estates. These bodies were to be government-owned but managed along business lines. ${ }^{22}$ The Presidential Regulation (Peraturan Presiden, PP) No. 19/196o integrated all government- and non-government owned companies into managerial bodies controlled by the state. The PP also required companies to give 55 per cent of their profits to the government. It dissolved the supervisory bodies and 'ambitiously codified the behaviour of all state enterprises and rigidly laid down rules governing the relationships between them in different sectors of the economy'. ${ }^{23}$ Governmentowned companies were to be integrated according to the type of industry they operated in, within what were called BPU. Thus, government-owned companies had at least three different layers of management: the ministry, the BPU, and the company management. This caused problems due to conflicting rules and policies.

During the colonial period, state-owned companies had provided a large share of total government revenue. In 1929, they had contributed up to 28 per cent of revenue, although by 1939 this had decreased to 14 per cent. By 1955, the total share of government revenue produced by state-owned companies had declined to 8 per cent. In comparison, taxes had climbed from forming 65 per cent of this total revenue in 1929 to over 90 per cent by $1951 .^{24}$ It was thus somewhat odd for the government to expect increased revenues from the

21 Bintoro Tjokroamidjojo, 'Perkembangan dan Evaluasi Tahap Penjelamatan Bidang Ekonomi dan Keuangan', in Bintoro Tjokroamidjojo, Tulisan-tulisan Administrasi Pembangunan, 1966-1968, 1-7.

22 J. Panglaykim and Ingrid Palmer, State Trading Corporations in Developing Countries. With Special Reference to Indonesia and Selected Asian Countries (Rotterdam: Rotterdam University Press, 1969), 7-8 and 16.

23 Panglaykim and Palmer, State Trading Corporations in Developing Countries, 17.

24 Douglas Paauw, Financing Economic Development. The Indonesian Case (Glencoe: The Free Press, 1960), 169-70. 
profits of state-owned companies. In fact, after 1960, state-owned company contributions to government coffers dipped to a lower level than the credit commitments made by the state banks which effectively subsidized the companies. Contributions declined from a level that just broke even with government credit to a whopping $1 / 102$ nd of the credit by 1965 , when government credit grew to Rp 527,11 billion with a measly Rp 5,13 billion in return contributions. ${ }^{25}$ State-owned companies became a liability.

Another reason for the deterioration of the economy was the reduction in the authority of the Central Bank as an independent body capable of determining monetary policies and thus fine-tuning the economy. Sjafruddin Prawiranegara, the head of the Bank of Indonesia, had resigned in February 1958 and joined the PRRI rebellion. By 196o, the вI had stopped publishing its weekly, quarterly, and annual financial reports. In 1961, the naming of Jusuf Muda Dalam, a PNI Sukarnoist, as the minister for central bank affairs and governor of the Bank of Indonesia, spelled the end of the bank's role as an independent monetary policymaker. Instead, the bank was there to support Sukarno's revolutionary plan. ${ }^{26}$

\section{The Dekon: Deklarasi Ekonomi}

At its heart, the Dekon was a rehabilitation measure meant to deal with inflation. Thus, monetary policy, that is, the Keynesian fine-tuning of the economy, was the main thrust of the rehabilitation process and its main policy was austerity. The Dekon was vaguely based on the Yugoslavian politicaleconomy model, ${ }^{27}$ although to what extent this was the result of studies by Indonesian economists is undetermined. Economists stressed the importance of austerity: 'As long as the government fails to rein in this strong inflation, then first, social efficiency will never be met and, second, the targets of the national plan will never be achieved. ${ }^{28}$ Mohammad Sadli said

25 Laporan Penelitian tentang Effisiensi Pembelandjaan Perusahaan2 Negara Periode 19601966 (Yogyakarta: Biro Penelitian Ekonomi FE-U GM, 1968), 3.

26 Radius Prawiro, Indonesia's Struggle for Economic Development. Pragmatism in Action (Kuala Lumpur: Oxford University Press, 1998), 3-4.

27 Mackie, Problems of Indonesian Inflation, 38.

28 Mohammad Sadli, 'Effisiensi Perusahaan dan Effisiensi Perusahaan Negara Dewasa Ini', Madjalah Perusahaan Negara, 3/28 (April 1963), 22. 'Selama pemerintah tidak dapat mentjegah inflasi jang keras maka, pertama, effisiensi sosial tak akan pernah tertjapai, dan kedua, target2 penanaman Rentjana Nasional djuga tak pernah akan tertjapai.' 
of the programme that 'now our price policies are based on more rational principles. ${ }^{29}$

The Dekon produced two quite different documents: the Deklarasi Ekonomi, announced on 28 March 1963, and, one month later, the May Regulations (Peraturan Mei), announced on 26 May 1963. The Dekon was a philosophical tract concerning the goal of the revolution, while the May Regulations detailed austerity measures and the efforts being made to relieve the economy from the inflationary spiral. Yet, the resulting Dekon had to accommodate various views. This blurring of the focus of the rehabilitation programme allowed for a sustained attack by the communists and, by the end of 1964 , their influence had become quite significant, resulting in a shift of emphasis towards expanding worker participation.

Indonesia had, in fact, started reaching out for international help in 1961 when the Humphrey Mission conducted a survey of the Indonesian economy. An IMF loan was procured in August 1961 to the tune of $\$ 41$ million to help the country's balance of payments. However, Indonesia was refused a loan from the World Bank because it was still required to pay indemnities to the nationalized Dutch enterprises. Indonesia had had strong inflation since 1952, which had accelerated further since 1957 and was lurching towards uncontrollable levels by $1961 .^{30}$ By late 1962 , the worsening economic situation was worrying Sukarno's inner circle. In November, Djuanda approached American ambassador Howard Jones to ask for American aid. At the same time, the Soviet delegation met with Soebandrio to discuss a trade credit for Indonesia worth $\$ 100$ million. ${ }^{31}$ Foreign Minister Soebandrio also approached the intellectual Soedjatmoko for help in formulating an economic programme for Indonesia. ${ }^{32}$ Soedjatmoko was part of a group of Indonesian intellectuals who met regularly to discuss the problems facing the country. According to Sarbini Sumawinata, he and the others in the group saw this request as an important opportunity to draw Sukarno closer to the technocratic group. ${ }^{33}$

Economists including Sarbini Sumawinata, Mohammad Sadli, and Widjojo Nitisastro ${ }^{34}$ no doubt contributed to the development of the Dekon. This

29 Mohammad Sadli, 'Stabilisasi Ekonomi sebagai Sjarat untuk Pembangunan Ekonomi jang Effektief', Madjalah Perusahaan Negara, 3/33 (September 1963), 8.

$30 \quad$ Mackie, Problems of the Indonesian inflation, 2-3.

31 Anwar, Sukarno, Tentara, PKI, 189-9o.

32 Soebandrio later disowned this claim and stressed that the Dekon was equally affected by communists such as Aidit. Anwar, Sukarno, Tentara, PKI, 233.

33 Sumawinata, 'Recollections of My Career', 49.

34 Thee Kian Wie (ed.), Recollections. The Indonesian Economy, 1950s-199os, (Singapore: ISEAS Publishing, 2003), 229. 
attempt to reduce the role of the state and allow the implementation of market forces seemed to be a challenge to the socialist experiment of the Guided Democracy. That Soebandrio, a senior member of the Guided Democracy elite, had now requested the help of the economists was a sobering indictment of the failure of the early Guided Democracy experiment. Soebandrio was competing with Djuanda to come up with an acceptable stabilization plan. ${ }^{35}$ The Dekon was launched on 28 March 1963 and in May a series of economic and fiscal reforms was announced, price controls were removed, and government subsidies were reduced. Sukarno's projects were halted and the government focused henceforth on agricultural and industrial production. ${ }^{36}$

In late 1962, the USAID mission ramped up its consultations with the economists in Djuanda's entourage. On 14 February 1963, an Indonesian delegation headed by Sutikno Slamet ${ }^{37}$ went to the United States for three weeks to hammer out an agreement and discuss debt-rescheduling and loans to Indonesia to the tune of $\$ 35$ o million. The delegation succeeded in convincing the authorities there of the sincerity of the Indonesian efforts to make economic reforms and acceded to stringent conditions. In March, the IMF sent its Indonesian executive director, Mr Sumanang, a former member of the Wilopo Cabinet, to reassure Indonesia that credit would be granted for the economic rehabilitation programme. ${ }^{38}$ In November, Indonesia requested the presence of an IMF mission to advise on stabilization measures. ${ }^{39} \mathrm{~A}$ team of ten experts was sent to draft technical details with their Indonesian counterparts. The report was said to have contributed heavily to the May stabilization regulations. ${ }^{40}$ The Kennedy Administration was hopeful that the core economic managers and technocrats around Djuanda would be able to wade through the political muck. ${ }^{41}$ Debt- rescheduling was an important component of the economic reforms being proposed. In April 1963, Indonesia discussed the issue with the Soviet Union. On 9 December, the United States proposed rescheduling Indonesia's debts to the Development Assistance Committee (DAC), a group of lender nations within the US orbit of influence, ${ }^{42}$ and discussed the possibility

35 Anwar, Sukarno, Tentara, PKI, 223-4.

36 John H. Sullivan, 'The United States and the New Order', PhD dissertation, American University, Washington DC, 1969, 42-3.

37 Chetwynd Jr., 'The Indonesian Stabilization Attempt', 41. He was a former director of the IMF and former financial adviser to President Sukarno.

38 Duta Masyarakat, 26 March 1963.

39 Bunnell, 'The Kennedy Initiatives', 214.

40 Chetwynd Jr., 'The Indonesian Stabilization Attempt', 41-2.

41 Bunnell, 'The Kennedy Initiatives', 75.

42 The Organization for Economic Cooperation and Development or OECD. 
of creating a coordinating group for Indonesia. ${ }^{43}$ This was a precursor to the later Inter-Governmental Group on Indonesia formed in 1967. Sukarno was convinced that he could get $\$ 600$ million from America relatively easily. ${ }^{44}$ Yet, after a report by the IMF, the government lowered its expectation to $\$ 400$ million from the US, the World Bank, the IMF, and other DAC members, such as the Uk, France, West Germany, and Japan.

Between February 1963, when Indonesia contacted the IMF, and March 1963, when the Dekon was announced, three separate committees were created in order to design and implement the economic programme. The first, the Committee of Five, was formed on 6 February 1963 and headed by Prime Minister Djuanda, Finance Minister Notohamiprodjo, Foreign Minister Soebandrio, Minister of Central Bank Affairs Sumarno, and Minister for Basic Industries and Mining Chaerul Saleh. The committee published a report that was heavily influenced by Djuanda and drafted with the help of his USAID-funded adviser, Bernard Bell, a private economic consultant. Djuanda's staff was successful because he knew many of the Indonesians working at the prime minister's office and there was a degree of trust. ${ }^{45}$ Yet, according to Rosihan Anwar, the president rejected Djuanda's plan on 27 February.

In early March, the Committee of Thirteen (Komite Tiga Belas) was created, again chaired by Djuanda, which drafted the basic strategic principles for future policy guidelines. This committee included more 'political' representation, including Dipa Nusantara Aidit and Muhammad Hatta Lukman of the PKI, Ali Sastroamidjojo of the National Front (Front Nasional), Idham Chalid of the Islamic church Nadhatul Ulama ( $\mathrm{NU}$ ) and various other political appointments. It was as part of the Committee of Thirteen that Soebandrio approached the economists and produced what was called the Economic Manifesto (Manifes Ekonomi). It was also through this committee that communist involvement became significant, allowing the communists to claim that the Dekon supported their economic policies. At a later date, the president named the last committee, the Committee of Seven (Komite Tujuh), which was to outline the government's economic policy. It was chaired by Dr Johannes Leimena and was dominated by political figures. ${ }^{46}$ The establishment of the Committee of Seven resulted in the further erosion of Djuanda's position, as he was not included in the committee. ${ }^{47}$ Djuanda's gradual loss of influence paralleled

43 Bunnell, The Kennedy Initiatives', 215.

44 Anwar, Sukarno, Tentara, PKI, 218.

45 Conversations about George Wood and the World Bank, S.5583, Oral History Transcript, World Bank Archives, Bernard Bell, personal archives.

46 Chetwynd Jr., 'The Indonesian Stabilization Attempt', 42-5.

47 Anwar, Sukarno, Tentara, PKI, 232-3. 
Soebandrio's rise. ${ }^{48}$ Unlike Djuanda's plan, Soebandrio's plan, co-written by the FEUI, was approved.

The rehabilitation programme was abandoned several months later after receiving little public support and decreasing international support as Western governments gradually lost faith in Indonesia. The 26 May Regulations, which were part of the IMF-endorsed stabilization programme, had dismantled price controls, resulting in increased fares for public transport and other austerity measures. Djuanda's role in coordinating the regulation was central. Other key figures included Finance Minister Notohamiprodojo, Central Bank Affairs Minister Sumarno, State Budget Minister Arifin Harahap, and executive governor of the World Bank and former Bank of Indonesia governor Sutikno Slamet, a good selection of Indonesian professional experts. ${ }^{49}$ Prices for postal services, transport, and electricity rose by between 400 per cent and 6oo per cent, while the salaries and allowances of civil servants were doubled. A new set of foreign-exchange regulations was introduced: $\$ 40$ million worth of foreign exchange was released as part of the 'crash programme' to import spare parts and raw materials to support industrial production, and the programme envisaged the halving of the 1963 deficit and its complete elimination by $1964 .^{50}$ The reaction from the political class was decidedly negative.

The PKI focused its attack on Djuanda and his heinous crime of 'liberalism'. By 7 September, Sukarno had issued a statement ordering the retraction of the rehabilitation measures. ${ }^{51}$ US ambassador Howard Jones announced that if Indonesia created a new cabinet of which the communists were a part, or if Indonesia escalated its Konfrontasi, ${ }^{52}$ the IMF deal would be off. ${ }^{53}$ This was due to the fact that, since early 1963 , the Russians had been pushing for a cabinet that included the PKI as part of the debt-rescheduling negotiation. ${ }^{54}$ Even so, because of the vague wording of the Dekon itself, its symbolic use

48 According to Rosihan Anwar, Djuanda was sour about this and did not attend a state meeting on the Dekon. Anwar, 'Pelopor Teknokrat', 216.

49 Chetwynd Jr., 'The Indonesian Stabilization Attempt', 39.

$50 \quad$ Mackie, Problems of the Indonesian Inflation, 39.

51 Rex Mortimer, Indonesian Communism under Sukarno. Ideology and Politics, 1959-1965 (Ithaca: Cornell University Press, 1973), 266-7.

$5^{2}$ Konfrontasi or the Indonesian-Malayan confrontation was a conflict started by Sukarno in opposition to the founding of the Federation of Malaya (Malaysia and Singapore), accusing the Federation as a neocolonialist creation of the United Kingdom. The confrontation occurred between 1963-1965 with Indonesian forces infiltrating Malayan Borneo and conducting operations in the Malay Penninsula and Singapore.

53 Anwar, Sukarno, Tentara, PKI, 234.

54 Mackie, Problems of the Indonesian Inflation, 37. 
was to continue throughout the period and a variety of people would claim to have been the main actors in its inception..$^{55}$ It is clear that, in the last instance, the Dekon document accommodated the wishes of both the PKI and the military, rendering it somewhat useless as the legal foundation of the rehabilitation programme. Its implementation was, according to Sjahrir, a ruse by Sukarno. ${ }^{56}$

On 15 May 1963, Sukarno's 'Ambeg Parama Arta' speech, meaning 'to prioritize essential matters', declared further changes to government policymaking. In it, Sukarno announced a series of sweeping changes for the Guided Democracy state. The speech declared the failure of the corporatist project of the early Guided Democracy state and its mascot, the corporatist Depernas body. Sukarno announced that the Depernas was to be incorporated within the executive government and run by the office of the president, similarly to the function of the BPN during the 1950s.

Sukarno's position on experts seems to have changed, at least briefly, during this period. Although he still loathed economists ${ }^{57}$ and proclaimed to have no knowledge of the economy in a speech he gave at the FEUI in $1964,{ }^{58}$ he warned members of Parliament that they had no constitutional right to tamper with details and 'matters I consider too complex'. ${ }^{9}$ He warned them to stay away from discussions of 'numbers' and other technical issues: 'Let those matters be in the hands of a specialized apparatus, made exactly for the purpose, in order for the job to be conducted in a perfect manner, because this work requires expertise and long work hours.' ${ }^{60}$ In March 1964, Sukarno asked for Hatta's help in solving the worsening economic situation, especially with

55 Anwar, Sukarno, Tentara, PKI, 236. The communists considered the Dekon to be the work of M. H. Lukman; a member of staff of the BI claimed that it belonged to Djuanda's staff, while an Indian military attaché claimed to have inside information that Prajudi Atmosudirdjo, then former head of the LAN, was involved. As Prajudi was a follower of Sumitro, it was then claimed that the PSI was involved.

56 Anwar, Sukarno, Tentara, PKI, 237.

57 For instance, in 1964 Emil Salim was surprised when he returned to Indonesia after finishing his doctorate degree to find that Sukarno had forbidden the reading of Western economic textbooks. Emil Salim, 'Emil Salim', in Thee Kian Wie (ed.), Recollections: The Indonesian Economy. 1950s-1990s, 197-8.

$5^{8}$ Soemardjan, 'Public and Private Enterprise', 81.

59 Sukarno, Ambeg Parama Arta, 31.

6o Sukarno, Ambeg Parama Arta, 32. 'Biarlah hal itu dikerdjakan oleh suatu Aparatur chusus, jang ditugaskan untuk keperluan itu, agar pekerdjaan dapat diselenggarakan dengan lebih sempurna, karena untuk keperluan itu diperlukan keahlian dan waktu-kerdja jang tjukup lama.' 
regard to the provision of rice. Hatta, in turn, asked for the help of Sarbini, Saroso Wirodihardjo, and Soedjatmoko in this quest. ${ }^{61}$

\section{The Dekon's Economic Measures}

As a document drafted by economists, the Dekon was pragmatic in its approach. Its focus on inflation control was in line with the measures that it intended to take to bring the economy to order. The measures included an austerity budget, a focus on rehabilitating the productive sector, the de-concentration and relaxation of controls over private and government-owned companies, the introduction of market mechanisms, the opening up of foreign participation, and increasing social control, that is, the participation of groups such as labour unions and farmers in the decision-making processes of companies through the implementation of company boards. The austerity measures included the elimination of price controls and subsidies, which would result in rising prices all round, but especially in transportation, a change that would badly affect the urban population with their fixed wages. ${ }^{62}$ Pushing through the implementation of these austerity measures would have required considerable strength of will from President Sukarno, but it became obvious to many that Sukarno was not willing. ${ }^{63}$

Rehabilitating the productive sector was difficult for a number of reasons, one of which being the difficulty of finding sufficient foreign exchange to import productive goods. Another major problem was the constraints that had been placed on managerial independence at the company level. Mohammad Sadli suggested that the BPUs should become a watchdog, part of the social control that would help to improve the social efficiency of the economy. ${ }^{64}$ Thus rehabilitation was intertwined with the need for de-concentration and the relaxation of regulations, allowing companies greater independence to determine levels of production, pricing, profit-making, marketing, and so forth. ${ }^{65}$ Companies were free to operate using a business mindset within an

61 Anwar, Sukarno, Tentara, PKI, 282. Saroso Wirodihardjo was an economist and the uncle of Sumitro Djojohadikusumo.

62 Bunnell, 'The Kennedy Initiatives', $381-2$.

63 Widjojo Nitisastro, The Indonesian Development Experience (Singapore: Institute of South East Asian Studies, 2011), xiv. 'In the short term, a stabilization programme to control inflation and a rehabilitation programme to build infrastructure were given particular priority.'

64 Sadli, 'Effisiensi Perusahaan', 18.

65 C. Siahaan, 'Pelaksanaan Dekon', Madjalah Perusahaan Negara, 3/31 (July 1963), 14-15. 
open environment and without being hampered by regulations of the various ministries and departments and the General Management Boards or regional officials. ${ }^{66}$ Although profits were on the increase, there were also increasing levels of state taxation. ${ }^{67}$ The gradual relaxation of control over the economy, moving it out of the hands of state bureaucrats, was envisaged. Government Regulation No. 7/1963 was one of the follow-up measures, which gave full autonomy to state trading corporations. ${ }^{68}$

Increased managerial independence from the central government, the BPUs, and the regional governments heralded efforts towards greater deconcentration. The central government's role in the economy was to be gradually reduced. For instance, import and export administration was to be devolved from central to regional offices. ${ }^{69}$

Mechanisms that worked within free-market economies were to be introduced as part of the effort to increase efficiency and productivity. As Sadli phrased it: 'Obviously, the price mechanism which is used in the interest of planning must not be left to its own devices; price mechanisms should be used in a guided manner! That is why the nature of competition is also limited, it is a guided competition!70 It was really a socialist competition. The idea of incentives was not merely to introduce market mechanisms, but to reach overall efficiency. Within a socialist economy, efficiency lay not within a particular company but within the overall economy. This was what Sadli termed 'social efficiency'.

Both production-sharing and joint-venture programmes were introduced as means to allow forms of foreign direct investment within the country. Development financing had become a major problem, only made worse by inflation. Introduced in 1962, it was hoped that it would act as a funnel for foreign investment in the extractive sectors of mining and oil. The funds committed were rather limited: $\$ 72$ million for the period $1962-1966$, a small fraction of the foreign borrowing Indonesia accrued. The biggest investment came from

66 Soenarto Soedibroto, 'Aktivitas PDN2 dalam rangka Dekon', Madjalah Perusahaan Negara, 3/34 (October 1963), 13-15.

67 In 1960, the profit of state-owned trading companies was at Rp 1.926,9 billion and in 1961 at Rp 1.425,1 billion. The profits given to the Overall Development Funds totalled Rp 503.9 million and Rp 648.3 million. 'Kolonel Soehardiman dihadapan Wartawan2 Ekonomi Ibukota tentang Fungsi BPU-PDN dan PDN2 dalam rangka Perpres No. 7, 1963', Madjalah Perusahaan Negara, 3/32 (August 1963), 10-13. By 1965, however, most of the companies had become unprofitable.

68 Panglaykim and Palmer, State Trading Corporations in Developing Countries, 70.

69 Sukarno, 'Deklarasi Ekonomi', Madjalah Perusahaan Negara, 3/28 (April 1963), 8.

70 Sadli, 'Effisiensi Perusahaan', 22. 
the Japanese at over $\$ 44$ million. Western Europe provided some $\$ 15.5$ million and Eastern Europe over $\$ 12$ million. ${ }^{71}$

Lastly, the ideas of social control, social support, and social participation became essential components of the reform process. The failure of the Depernas project and its incorporatist forms of national planning had not lessened Sukarno's support for some form of participation that should be extended into the wider economy. If national planning had to be returned to within the central governing bodies of the Bappenas-Muppenas at the company level, the participation of social organizations should be achieved through access at the managerial level. The creation of the company boards thus allowed for the participation of trade union organizations within the policymaking bodies of companies and was an effort to democratize managerial relations within companies. The company boards were intended to change the labourmanagement relationship from one of employment to one of human and social relations, with the aim of increasing the quality of production. ${ }^{72}$

The failure of the Dekon was understood to be the result of the inability of Sukarno's government to maintain discipline. The beginning of the Konfrontasi with Malaysia and Singapore shifted the political focus, while austerity measures were not maintained. Popular support for the economic rehabilitation programme remained low. Bunnell has suggested that the reason for this was that the business sector represented only a small percentage of the Indonesian urban population. The vast majority of Indonesians were farmers, whose lives were less affected by the monetary sector of the urban economy. At the same time, the bureaucracy and the military were protected from inflation through a combination of government subsidies and corruption. ${ }^{73}$ The support for the programme from urban wage earners was understandable when it is considered that wages were lagging behind price increases due to the easing of price controls and the removal of some government subsidies. ${ }^{74}$

71 Joyce Gibson, 'Production Sharing: Part II', Bulletin of Indonesian Economic Studies, 4/2 (1966), 75-100.

72 Nurdjaman, 'Dewan Perusahaan sebagai Alat Revolusi dalam kerangka Tata Susunan Perusahaan Indonesia', in Kumpulan Kertas Karya Musyawarah Besar Sardjana Ekonomi. Djakarta, 15 Djuli 1964, Jilid I (Jakarta: Jajasan Badan Penerbit, 1964).

73 Frederick Phillip Bunnell, 'The Kennedy Initiatives in Indonesia, 1962-1963', Thesis, Graduate School of Cornell University, 1969, 411-12. Bunnell, 'The Kennedy Initiatives in Indonesia, 1962-1963', 381. 
The PKI immediately launched opposition to the May Regulations. The Youth Front (Front Pemuda) said that it benefited only the capitalist bureaucrats, compradors, and corruptors. ${ }^{75}$ Carmel Budiardjo attacked its Western economic viewpoint for failing to link the problem of inflation with the problems of production. ${ }^{76}$ The production approach was meant to 'concretely free the productive forces which would push through the basic strategy of the Indonesian economy'.77 The communists championed this shift from monetary policy to production policy because it would provide them with access to the so-called bureaucratic capitalist productive economy, which was in the hands of the military. ${ }^{78}$ The process of de-concentration was also attacked. The communists wanted more government intervention, not less. According to Budiardjo, 'the corruptors, who had to be eliminated through changing the price policies, by eliminating price controls, and by letting the price of governmentowned companies meet market prices, were not eliminated. In fact, they grew because their actions were no longer supervised by the government. ${ }^{\prime 79}$

In other words, according to the communists, the floating of the currency and the reintroduction of market mechanisms had no effect on eliminating inflation. Budiardjo argued that the only way inflation could be handled was through the structural incorporation of the working class in the economy, which would allow them to participate in the management of companies and the economy. This was what the communists understood by the idea of social control: the control of the economy by 'society'.

\section{$7 \quad$ Communist Views}

The international context of the Cold War was well understood by both military-leaning and PKI-leaning economists and intellectuals. PKI sympathizers, such as Carmel Budiardjo and J. B. A. F. Major Polak, a former PSI

\footnotetext{
75 'Mengobarkan Gerakan Anti-Korupsi dan Menatasi Krisis Sandang-Pangan. Memorandum Front Pemuda', in Perekonomian Nasional, 4/47 (December 1964), 21-3.

76 Carmel Budiardjo, 'Melaksanakan Dekon dengan Konsekwen. Kesulitan Ekonomi Dewasa Ini Dapat Diatasi', Perekonomian Nasional, 4/47 (December 1964), 9-11.

77 Budiardjo, 'Melaksanakan Dekon dengan Konsekwen', 9-11.

78 Kabir: kapitalis birokrat.

79 Budiardjo, 'Melaksanakan Dekon dengan Konsekwen', 11. 'Tukang2 tjatut jg mau dibasmi dengan mengubah politik harga ketika itu, jaitu menghapus sisteem pengendalian harga dan membiarkan harga2 pendjualan badan2 milik pemerintah menjesuaikan diri dengan harga pasar, bukannja dibasmi, tetapi lebih berkembang karena kegiatanznja sudah tidak diawasi lagi.'
} 
politician, openly discussed the Cold War front, the dangers of Kennedy's shift of emphasis to politicized foreign aid, and his obsession with guerrilla warfare, as explained by Stewart Alsop. ${ }^{80}$ The threat of the America-dominated Bretton Woods institutions and the Alliance for Progress was voiced after the IMF-influenced Dekon in 1963. Aidit warned of the dangers of American neocolonialism through aid and pointed to the case of Brazil. ${ }^{81}$ In an article in the communist newspaper Harian Rakjat, he commented that 'pragmatism is always praised as a "practical" philosophy and that the "practicality" of pragmatism has an evil but practical role for the imperialist'. ${ }^{2}$ This was an attack against what he saw as Indonesia's appeasement of the IMF and against the Indonesian economic reform programme.

The shift towards seeking the advice of experts during the late Guided Democracy highlights a period of intellectual feuding between American-trained economists and PKI-affiliated economists. Mohammad Sadli commented that, 'within FEUI there was a political struggle with Carmel Budiardjo and other left-wingers in the Faculty'. ${ }^{83}$ The HSI became a contender for the LPEM, publishing works that focused on the dangers of American intervention. It included intellectuals such as F. Runturambi from the Central All-Indonesian Workers Organization (Sentral Organisasi Buruh Seluruh Indonesia, sовSI), a PKI-affiliated labour organization, Professor Ernst Utrecht, and Drs. Soerjadi, the minister for budgetary affairs.

An examination of Aidit's speeches and of his paper on the Dekon and the economy in general provides a picture of the position of communist ideas visà-vis those of the experts trained in the US. It was all about the application of what they termed a production policy that would work against the monetary stabilization advocated by FEUI economists. ${ }^{84}$ 'It has been the case for too

8 J J. B. A. F. Major Polak, 'Pembahasan Atas Prasaran Ke-II', in Sukirna, Untuk Pelaksanaan Dekon. Hasil-hasil Seminar Ekonomi jang Diselenggarakan oleh Lembaga Ilmu Ekonomi HSI (Jakarta: Departemen Urusan Research Nasional, 1964), 174-92.

81 Harian Rakjat, 29 January 1963.

82 Harian Rakjat, 27 March 1963. 'Filsafat imperialis adalah pragmatisme, jaitu filsafat jang mengukur segala sesuatu dari sudut apakah akan membawa keuntungan2 bagi saja atau tidak.' Pragmatisme selalu dipudjiz sebagai suatu filsafat jang "praktis" dan ternjata bahwa sifat "kepraktisan" dari pragmatisme memang mempunjai peranan jang djahat tetapi praktis benar bagi kaum imperialis sendiri.'

83 Sadli, 'Recollections of my Career', 38-9.

84 According to Penders and Sundhausen, Abdul Haris Nasution, 164, 'the PKI had nothing to gain from an improvement of the living conditions of the masses; this would have diminished its opportunity to mobilize them for its purposes and, moreover, would have brought the "PSI-leaning" technocrats back into positions of economic power'. Even if it were so, it would seem too hasty to dismiss communist ideas on economic development. 
long that Indonesian economics experts have taken a position of ignorance regarding political issues and have tried to present the problems of the economy as merely a technical matter, with laws that "were assumed to apply in all ages", which stemmed from a subjective viewpoint and ignored the objective reality that exists within society. ${ }^{85}$ According to the communists, economic policymaking should have been derivative of the political process and the national goal of the revolution. As Aidit phrased it: 'The viewpoint that socialism can be implemented without first dealing with the national democratic effort, that is, the ending of the residues of imperialism and feudalism, is intolerable. ${ }^{86}$

The communists supported two laws introduced in 1960 as heralding the ending of imperialism and feudalism in the country: the Regulation on the Agreement of Joint Revenue Sharing (Undang-undang Perdjandjian Bagi Hasil, UUPBH) and the Regulation on Basic Agrarian Principles (Undang-undang Peraturan Dasar Pokok Agraria, UUPA). According to the communist interpretation, the UUPBн would prohibit foreign direct investment by diverting it to revenue-sharing projects. This was a victory over imperialism, as it limited the role of foreign enterprises. The continued nationalization of British and American-owned enterprises during the period $1963-1965$ was also part of this anti-imperial strategy. The UUPA would destroy what was known as the landlord class of the agricultural community through a process of land redistribution. This land-ownership reform formed the anti-feudal strategy.

The clash between 'Western' and communist economists occurred over these strategies. Aidit accused Sumitro of siding with imperialists and feudalists because he blamed Indonesian poverty on the population's lack of savings. This was part of the reigning Harrod-Domar model, which saw the root of poverty as being a result of the subsistent nature of the economy and the lack of reinvestment in production, that is, an acknowledgement that growth can only occur when the rate of savings is greater than the capital output ratio

85 Dipa Nusantara Aidit, Pemetjahan Masalah Ekonomi dan Ilmu Ekonomi Indonesia Dewasa Ini (Jakarta: Jajasan Pembaruan, 1964), 4. 'Sudah terlalu lama kaum sardjana ekonomi Indonesia pada umumnja mengambil sikap masa-bodoh terhadap masalah politik dan berusaha membahas masalah ekonomi sebagai masalah jang bersifat teknis melulu, dengan hukum-hukum "jang berlaku untuk semua zaman" jang bertolak dari pandangan-pandangan subjektif dan mengabaikan kenjataan objektif jang hidup didalam masjarakat.'

86 Aidit, Pemetjahan Masalah Ekonomi, 6. 'tidak dapat ditolerir lagi pendapat bahwa sosialisme bisa diselenggarakan tanpa menjelesaikan lebih dahulu perdjuangan nasionaldemokratis, jaitu tanpa menghabis-tamatkan lebih dahulu sisa-sisa imperialisme dan feodalisme.' 
and the growth of the labour force. ${ }^{87}$ The solutions they propounded were the injection of capital by foreign direct investment or loans and the incentivizing of Indonesians to save their incomes.

It was an analysis that, according to the communists, lacked a social component and misunderstood the nature of Indonesian rural society. According to them, the reason for the lack of savings lay not in the lack of a propensity to save among the Indonesian farmers and labourers, but in the rent-seeking activities of bureaucratic capitalists, foreign-enterprise owners, and the landlords in the villages. The main criticism against Western-educated economists was that they harboured apolitical ideas. Aidit continued: "The most significant contributor to this evil analysis is Sumitro, a person who is famous and well known to be rebellious and traitorous to the Republic, but whose equally traitorous and heinous economic theories have not yet been properly disrobed and are given an important place in our universities and still colour the thinking of the officers that man our economic-policy apparatuses. ${ }^{\text {' }} 8$

The PKI had always held an ambiguous position in relation to experts and intellectuals. In many communist movements outside Indonesia, intellectuals represented a major part of the communist movement, yet in Indonesia this was not the case. The lack of expertise in the nation meant that the vast majority of university graduates had an almost assured position in government jobs and there was no pool of unemployed intellectuals. ${ }^{89}$ In the early 1950s, the communists still regarded intellectuals as an important part of the movement, but aside from the HSI and the People's Cultural Institute (Lembaga Kebudayaan Rakjat, Lekra) - an artists' and writers' organization - there was no prominent intellectual organization within the PKI. The attack on intellectuals was accentuated by the conservative nature and 'reactionary' position taken by the apolitical Indonesian economists. As a result, the PKI supported a non-expert, participatory approach to economic problems. The failure of the rehabilitation programme known as the May Regulations supported this idea:

87 Robert M. Solow, 'Growth Theory and After', The American Economic Review, 78/3 (June 1988), 307-17. In a work published in 1957, Solow contributed to the theory by adding technology as a factor that increases productivity growth.

88 Aidit, Pemetjahan Masalah Ekonomi, 12. 'jang paling "berdjasa" dalam menjebarkan analisa jang djahat ini jalah Sumitro, seseorang jang sudah terkenal dan sudah telandjang bulat sebagai pemberontak dan pengchianat terhadap Republik, tetapi jang teori-teori ekonominja jang sama chianat dan sama djahatnja belum tjukup ditelandjangi, masih mendapat tempat dalam perguruan-perguruan tinggi kita dan masih mendjiwai pegawaipegawai tinggi dalam aparatur ekonomi kita.'

89 Donald Hindley, The Communist Party of Indonesia, 1951-1961 (Berkeley: University of California Press, 1964), 183-184. 
This signified the triumph of the Indonesian people, because for the first time our people can directly and actively determine government policy on economic matters, a field that has long been considered to be beyond the ken of the people, a field that it was said can only be thought of and discussed by certain experts, whose expertise has failed us in dealing with the economic and monetary issues at hand. ${ }^{90}$

The idea of production policy thus belittles the problems of inflation and the monetary approach. Keynesianism was the target of recrimination for both Sukarno and the communists. Yet, the attacks on Western-educated experts such as Sumitro Djojohadikusumo had a strawman-like quality. Carmel Budiardjo's idea of fair practices for small agricultural producers and better access to capital and foreign markets ${ }^{91}$ was not received particularly poorly by people like Widjojo Nitisastro, whose work had also focused closely on small agricultural producers. ${ }^{92}$ As Runturambi of the sobsi said: "The believers in these economic theories ruminate night and day to find a "new theory" that is not Russian, not Chinese, not totalitarian and that does not use the formulas commonly used by anti-communist and anti-Nasakom lecturers within and outside the country. When they find it too hard to call their theories socialist, they use the American term "people's capitalism".'93 That economic policy meant

9o DN Aidit, Dekon dalam Udjian (Jakarta: Jajasan Pembaruan, 1963), 8. 'ini menggambarkan suatu kemenangan bagi Rakjat Indonesia, karena dengan ini berarti bahwa untuk pertama kalinja Rakjat kita setjara langsung dan aktif ikut menjusun politik Pemerintah dibidang ekonomi, jaitu sudatu bidang jang selama ini dianggap sebagai bidang terlarang untuk Rakjat, suatu bidang jang katanja hanja dapat difikirkan dan diperbintjangkan oleh tenaga-tenaga ahli tertentu jang sudah terbukti sama sekali tidak berhasil mengatasi kesulitan-kesulitan ekonomi dan keuangan selama ini.'

91 Carmel Budiardjo, 'Perdagangan Luar Negeri: Segi Dalam Negeri (Produksi dan Marketing) dan Segi Luar Negeri (Neratja Pembajaran)', in Sukirna (ed.), Untuk Pelaksanaan Dekon. Hasil-hasil Seminar Ekonomi jang Diselenggarakan oleh Lembaga Ilmu Ekonomi HSI (Jakarta: Departemen Urusan Research Nasional, 1964), 71-101.

92 This, what is now termed a 'pro-poor' policy focused closely on rural agricultural development, an important component for the success of New Order development. Jan Kees van Donge, David Henley and Peter Lewis, Tracking Development in Southeast Asia and Sub-Saharan Africa: The Primacy of Policy', Development Policy Review, 3o, s.1 (February 2012), $12-16$.

93 Runturambi, 'Potensi Ekonomi dan Kekuatan Politik sebagai Landasan Pelaksanaan Deklarasi Ekonomi', in Sukirna (ed.), Untuk Pelaksanaan Dekon. Hasil-hasil Seminar Ekonomi jang Diselenggarakan oleh Lembaga Ilmu Ekonomi HSI (Jakarta: Departemen Urusan Research Nasional, 1964), 29. '[...] penganut teori ekonomi itu seperti siang dan malam hanja berfikir bagaimana bisa menemukan "teori baru" jang bukan Rusia, bukan RRT, bukan totaliter dan matjam2 rumus jang lazim digunakan oleh lektur anti komunis dan anti Nasakom didalam dan diluar negeri. Malahan kalau sudah terlalu sulit memalsu 
nothing without political control was understood by both sides; Runturambi's article was titled 'Economic Potential and Political Power as the Foundation for the Implementation of the Dekon'. Along with the belief in an agricultural approach to development, it represented ideas that were agreed upon across the board. The struggle was a political one for authority and legitimacy as much as one of basic economic theory.

\section{$8 \quad$ Regional Development and the Military}

The problems related to regional development were apparent to those studying the integration of former rebel areas in places such as Northern Sumatra. J. E. Ismael's visit to the area from October 1961 to February 1962 highlighted the enormous problems related to integrating national development planning with regional government capabilities:

In Indonesia, the National Overall Development Plan has become a reality. Various projects will be built throughout the regions; some are not yet explicitly detailed, and others will be built to complement other projects. As a result, the National Overall Development Plan is functioning as an index in its initial phase, similar to Russia's Gosplan development plan, and will ultimately form an 'integrated regional development plan'. ${ }^{94}$

Mohammad Sadli observed that 'regional development was an "ideological commitment" of socialism, at least within the socialism that was practised in countries ruled by communists. ${ }^{95}$

sosialisme dan terpaksa harus menggunakan istilah kapitalisme dipilihlah istilah "kapitalisme kerakjatan" model Amerika Serikat.'

94 J.E. Ismael, 'Beberapa Aspek Institusionil dalam Pembangunan Nasional dan Daerah', in Sukirna (ed.), Laporan Kongres Ilmu Pengetahuan Indonesia Kedua, 1962, Djilid Ix: Seksi E-3 (Ekonomi) (Bogor: Archipel, 1962), 130. 'Di Indonesia sekarang ini PPNSB sudah mendjadi kenjataan. Projek2 jang akan dibangun tersebar didaerah2, ada jang belum lengkap terperintji, dan ada pula jang perlu dikomplemenkan. Dengan demikian maka: PPNSB mendjalankan fungsi sebagai index dalam permulaan proses penjusunan rentjana pembangunan oleh Gosplan di Sovjet Rusia, atas dasar dan sekitar mana daerah menjusun rentjana pembangunannja, jang kesemuanja achirnja harus berwudjud mendjadi suatu "integrated regional development plan".'

95 Mohammad Sadli, 'Beberapa Segi Masalah Pembangunan Daerah di Indonesia', in Laporan Kongres Ilmu Pengetahuan Indonesia Kedua, 1962, Djilid Ix: Seksi E-3 (Ekonomi) (Bogor: Archipel, 1962), 97. 'Pembangunan daerah djuga merupakan suatu "ideological 
There was a deep realization that the economic problems in socialist societies were problems related to the political economy. The problem of justification within the acuteness of the economic rationality of the economic model had to be solved. Mohammad Sadli asked the question:

To an economic expert the problem is a question of conscience (gewetensvraag), meaning does he need to find a 'justification' for all the deviations from resource allocation that matches pure economic considerations in a way that the decisions can be accounted for from an economic perspective? Or should he consider these deviations as an unwarranted but unavoidable aspect of his economy, as part of the social cost of economic development, as a necessary waste? ${ }^{96}$

The answer, according to Sadli, lay in the creation of a development leadership. Yet, instead of pointing a finger at the nascent managers, he pointed to the obvious leaders of the regions during the period: the military. ${ }^{97}$

The current military men have power over a wide area. Although they admit to the importance of regional development, they are often unable to collect the funds and forces needed to start this development. Despite this, because they are the most powerful group at present, their potential to play a role in development leadership is great. Of course, the mental

commitment" dari sosialisme, setidak2nja sosialisme seperti jang diamalkan dalam negeri2 jang dewasa ini diperintah oleh kaum komunis.'

96 Sadli, 'Beberapa Segi Masalah Pembangunan Daerah', 94. 'Bagi seorang sardjana ekonomi masalah demikian merupakan suatu "gewetensvraag", artinja haruskah ia mentjari suatu "justification" untuk penjimpangan2 dari resource allocation menurut pertimbangan2 ekonomi jang murni sedemikian rupa sehingga achirnja keputusan2 ini dapat dipertanggung-djawabkan djuga dari segi ekonomi? Ataukah ia harus bersikap bahwa penjimpangan2 ini sebetulnja tidak dapat diharapkan kefaedahan ekonominja tetapi harus diterima sebagai bagian dari "social costs of economic development", jakni jang bersifat "waste" (tetapi "necessary waste").'

97 According to Mrazek, 1959 was an annus mirabilis during which the military began to enter into the politics of various young states and, more importantly, the academic community began to entertain the possibility of supporting military managers as modernizers. Mrazek, The United States and the Indonesian military, 14. Peter Dale Scott considered 1958 to be an important year as this was when new mandarins, including Edward Lansdale and Guy Pauker, started selling the military as a possible modernizing candidate. Scott, 'Exporting Military-Economic Development', 210. Bradley Simpson argued that 1963 was the important year in this regard, as it was when military modernization theory became widely accepted in policymaking circles in Washington. Simpson, Economists with Guns, 71-2. 
capabilities and understanding, the tools and willpower must be attended to. At the moment, and as has been the case for the last couple of years, they occupy a dubious position. They are in charge of security but not in direct charge of welfare. But increasingly there has been greater awareness amongst them that regional security cannot be separated from the welfare of the people and that this cannot be separated from economic development. Thus, lately they have been more responsible for the welfare and wealth of the regions. Security is a complex issue and is not purely a military or police problem. If the problem of security has become such a complex issue then everyone is responsible for general welfare; even during times of military law (SOB), it is not purely the responsibility of the military, as it is not purely the responsibility of civilians during peacetime. It requires a collective sense of responsibility, at least between military and civilian groups on the matters of security, welfare, and economic development. Does that mean that the military and civilian, the green and white shirts should become pioneers of regional development? The concept of such leadership is autocratic and may not be effective in the long run, but such an autocratic approach may be strong enough to create a momentum to kick-start development. ${ }^{98}$

98 Sadli, 'Beberapa Segi Masalah Pembangunan Daerah', 118-19. 'Kaum militer dewasa ini sering mempunjai kekuasaan jang tersebar didaerah. Biarpun mereka ini mengakui pentingnja pembangunan daerah, namun sering merekapun merasa tidak mampu untuk menghimpun "funds and forces" untuk memelopori pembangunan ini. Biarpun demikian, djustru oleh karena golongan ini dewasa ini adalah jang paling berkuasa, maka potentiil merekalah jang paling mampu untuk memainkan peranan development leadership ini. Sudah tentu mentale instellingen, begripnja, peralatannja dan kemauannja harus dipupuk terus. Pada saat ini, serta djuga dibelakang hari, posisi mereka agak dubieus. Mereka bertanggung djawab atas keamanan, tetapi tidak langsung atas kemakmuran. Akan tetapi, lambat laun telah timbul suatu keinsjafan dikalangan mereka bahwa keamanan daerah tidak dapat dilepaskan dari kesedjahteraan rakjatnja, dan ini tidak dapat dipisahkan dari pembangunan ekonomi. Maka achir2nja merekapun merasa bertanggung djawab atas kesedjahteraan dan kemakmuran ini. Akan tetapi, dengan demikian maka soal keamanan mendjadi masalah jang komplex, tidak hanja berupa masalah militer atau polisionil. Kalau masalah keamanan mendjadi demikian komplexnja maka sebetulnja semua fihak bertanggung djawab terhadap masalah kesedjahteraan pada umumnja; dalam masa sов-pun bukan fihak militer sadja, dan dalam masa damai bukan fihak sipil sadja. Ini memerlukan rasa tanggung-djawab kolektip, setidak2nja antara kaum militer dan kaum sipil terhadap masalah keamanan, kesedjahteraan dan pembangunan ekonomi. Apakah lalu kaum militer dan sipil ini, kaum badju hidjau dan badju putih bersama2 dapat mendjadi pelopor dalam pembangunan daerah? Konsep pimpinan demikian masih tetap otokratis dan mungkin tidak akan effektip untuk masa jang pandjang. Akan tetapi approach jang serba otokratis ini mungin tjukup kuat untuk menimbulkan suatu momentum untuk permulaan pembangunan.' 
The argument that military autocracy was necessary to regulate the immediate problems of a political economy was one that was openly expressed by economists during the period. Sadli's views were congenial to the military elite; enough for Colonel Soewarto of the Seskoad, an old friend of Sadli from his Yogyakarta days, to invite him and his economic friends at the FEUI to teach there. ${ }^{99}$ Both Sadli and Suwarto saw this as a rational solution to an intractable societal problem. Economic planning and military leadership, or at least military participation, had assumed considerable importance within the Guided Democracy state. It was not certain whether the extent of the contribution from the military to corruption was understood amongst economists. The reports of the Bapekan, for instance, may not have been made available to intellectuals.

Importantly, the idea was not purely of military rule, but of a rule shared between the green and white shirts. Thus, Presidential Decision No. 655/1961 on Regional Planning (Keputusan Presiden No. 655/1961 tentang Perentjanaan Daerah) recreated regional governance within a Tjatur Tunggal system that put the military regional commander in power, at least for the duration of the military emergency. The ideas of civic action and development were thus very much intertwined. Ibrahim Adjie said this of the army's connection to development: 'War is not the goal of the military; the goal of the military is to uphold the welfare and honour of the nation so as to be level with the most advanced nations in the world. 100

Where were the managers in this picture, then? Was there such a deep distrust of the capability of Indonesian management that economists such as Mohammad Sadli put their trust in the military men? Panglaykim's study of the Soviet system noted two distinct generations: a politicized managerial elite what Joseph Berliner called the 'Red Directors' - who obtained their positions through their political affiliations and roles during the revolution, and a new, educated elite, who were products of the new education system and had a professional attitude to management. In the words of Panglaykim: 'In my viewpoint, the executives trained during the revolution and those who have had a formal education are very different. Those who have had a formal education are educated to direct their energy and minds to the service of the state and are interested in creating the largest industrial nation on earth. Thus, those with education as their capital form a very worthwhile corps.'101

99 Mohammad Sadli, 'Mohammad Sadli', in Thee Kian Wie (ed.), Recollections. The Indonesian Economy, 1950s-1990s, 125.

100 Adjie, 'TNI dan Civic Mission', 13.

101 Panglaykim, 'Beberapa Aspek Struktur Management', 172-3. 'Menurut pandangan kami memang berbeda sekali para eksekutif jang telah dilatih pada masa revolusi dan mereka 


\section{$9 \quad$ Conclusion}

The series of institutional reforms that was conducted during the Guided Democracy resulted in several significant developments. First, the failure of corporatism in national planning, as exemplified by the Depernas, led to a push for the inclusion of experts and managers in the managing of national and regional policies. Second, the Bappenas-Baperdep-Bakopda structure offered the potential for greater centralized control. The fact that the Bakopda conformed to the Tjatur Tunggal structure meant that the regional governments were finally recreated under the authority of regional planning agencies in which managers - military and civilian - were able to partipate. Instead of decentralization, the New Order state did away with regional democracy and regional government. It instituted a form of national and regional military control with the cooperation of both the Pamong Praja and the managers.

In the early 196os, Western-educated economists trained their sights on studying and understanding the development of socialist institutions in communist countries. Using the examples available in various communist countries, their goal was to create a socialist model that would allow for some inclusion of market mechanisms, market incentives, decentralization, de-concentration, and a general reduction of state intervention in the economy. The P KI attacked their focus on the problems of inflation and the usage of monetary and fiscal policies, considering it part of a larger Western conspiracy to derail the revolution. The monetary policy was considered by the PKI as merely supporting the corruption of 'capitalist bureaucrats', the derogatory term used for managers, especially military managers. Instead, the communists advocated the greater inclusion of workers in what they called production policy.

jang telah memperoleh pendidikan formil. Mereka jang memperoleh pendidikan formil memang terdidik untuk mentjurahkan tenaga dan fikiran bagi kepentingan negara dan berkehendak mentjiptakan suatu negara industri jang terbesar didunia. Dengan modal pendidikan, mereka merupakan suatu corps jang berharga sekali.' 